\title{
WHAT DO VIETNAMESE EXECUTIVES UNDERSTAND CORPORATE SOCIAL RESPONSIBILITY?
}

\author{
Le Thi Thanh Xuan, Lai Van Tai, Truong Thi Lan Anh \\ School of Industrial Management \\ Hochiminh University of Technology, Vietnam \\ lttxuan@hcmut.edu.vn
}

(Received:16/09/2013; Revised: 06/12/2013; Accepted: 20/01/2014)

\begin{abstract}
The Corporate Social Responsibility (CSR) literature in developing countries is seriously meager. This paper explores CSR in the Vietnamese construction industry which has faced many scandals and directed attention toward the question of the responsibilities of these businesses. The study employs the CSR definition documented by Carroll $(1979 ; 1991)$ to develop a framework for exploring executives' perceptions towards CSR. Using Carroll's CSR pyramid and adopting in-depth interview as a method to collect data, the study critically examines the personal understanding of managers in nine companies in the construction industry. The findings show that although Vietnam is a developing country, managers are aware of the significance of environmental issue as a responsibility that businesses must address. Moreover, the managers also believe that corporate contributions to society, and corporate reputation and prestige, are expectations of society. Despite many breakthroughs in executives' understanding of CSR, they are not sufficiently and systematically aware of CSR and need a stronger supports, such as issuing appropriate policies, from government in adopting CSR in real business practice.
\end{abstract} Country.

Keywords: Corporate Social Responsibility, Perception, Awareness, Developing

\section{Introduction}

Corporate social responsibility (CSR) is now becoming a significant aspect that needs to be prioritized in business life. The number of companies paying attention to CSR is increasing dramatically. In order to adopt and integrate CSR in business strategies, it should be affirmed that the role of leaders in disseminating CSR initiatives are essential. Moreover, CSR now is "an inescapable priority in a business leader" (Porter and Kramer 2006).

Leaders adopt CSR in business to satisfy consumer expectations in order to achieve increased sales and market share, strengthen brand positioning, enhance corporate image and clout, increase their ability to attract, motivate and retain employees, decreased operating costs, and increase appeal to investors and financial analysts (Kotler and Lee 2005). As well, businesses need to develop methods to analyze and implement CSR decisions (Paine 1996). CSR should be incorporated in business as a strategic choice made by the leaders and it will return for allocated resources, such as time, financial or human capital (Waldman and Siegel 
2008). While executing responsibilities, leaders, especially CEO, aim to shape the culture of the firm by their own values and characteristics (Berson, Oreg et al. 2008) which significantly impact the manner of decision making and CSR undertakings (Agle, Mitchell et al. 1999).

In other words, the leader will have a significant influence on the organizational life which is only secondary to the influence of the owners of the business. The leader will shape the values of the organization by building up its characteristics with ethical lessons and moral triumphs (Ciulla 1999). The role of the leader is crucially concerned to the point that he/she can adopt CSR in business for the main purpose of maximizing the benefit of shareholders (Waldman and Siegel 2008). Moreover, this influence not only affects employees but also other stakeholders, such as consumers, government and community (Berson, Oreg et al. 2008; Waldman and Siegel 2008).

Although CSR has a long history in developed countries, its literature in developing countries is still meager. There are not many studies investigating managers' understanding of CSR. In Vietnam, CSR has recently been receiving much attention. In 2005 the CSR Vietnam forum (http://www.csrvietnamforum.net) was initiated in order to provide CSR resources and information for businesses. In 2008, the scandal of the Vedan Company which discharged a large amount of untreated sewage into the Thi Vai River raised serious concerns in the neighboring communities and throughout the country about the social and environmental responsibilities of business. Research on CSR in Vietnam has been seriously limited. In particular, there is no research on how Vietnamese managers perceive CSR.
This study is conducted in the construction industry. To justify selecting the construction industry as the focus of this research, there are some salient factors. First, the construction industry has developed rapidly in recent years and has emerged as an important sector contributing significantly to the development of Vietnam (Quan 2010). Its critical role has been promoted by government and has heavily influenced Vietnam's economy as well as the employed population (Bo 2009). Secondly, the limitations of many aspects in operating and managing projects lead to the poor quality in construction projects, workplace accidents, and corruption (Bo 2009; Ling, Pham et al. 2009). Lastly, the construction industry impacts heavily on the societal and stakeholders' environment and well-being (Murray and Dainty 2009).

This study will help address the gap in CSR literature in developing countries. It examines the perceptions of Vietnamese managers in the construction industry toward CSR. This study also examines managers' perceptions about the role of government and professional associations in encouraging construction companies to adopt CSR practices in their operations.

This study is significant in providing a detailed picture of CSR in the mind of practicing managers. Therefore, it will provide the guidance for the construction industry and government in issuing policies and setting rules in practice.

\section{Literature Review}

\section{Carroll's CSR conceptualization}

In his 1979-study, Carroll (1979) integrated all relevant aspects of CSR and articulated a definition to cover the whole responsibilities that business have to respond in order to satisfy stakeholders' expectations. This definition should 
include the economic, legal, ethical and discretionary responsibilities.

\section{Economic responsibilities}

According to Carroll (1979; 1991), in order to exist in a competitive market, business, which is defined as 'the basic economic unit', is required to be profitable. Therefore, it is easy to recognize that profitmaking a crucial obligation that a business has to satisfy its owners in maximizing earning per share, maintaining a strong competitive position and a high level of operating efficiency.

\section{Legal responsibilities}

Economic missions should be fulfilled within the framework of the law (Carroll 1979; 1991). These responsibilities are as fundamental as the economic responsibilities are (Carroll 1991) and determined by the public or government who is representative for the public (Dalton and Cosier 1982).

\section{Ethical responsibilities}

There are many issues that are still debated by the public as to whether they are ethical or legal (Carroll 1979), and new ones may emerge. Hence, ethical responsibilities are derived from 'newly emerging values and norms' (Carroll 1991, p.41) and are not necessarily documented in laws or requirements (Carroll 1991; 1998). Because of not codifying these into law, such obligations are not compulsory but they are stakeholders' concerns and may move to the legal responsibility category at a future time.

\section{Philanthropic responsibilities}

CSR is not restricted to philanthropy. These philanthropic duties are only one of business's responsibilities. This category of responsibility is not mandatory, not framed into law, not considered as ethical activities; but it is what business does to be a good citizen (Carroll 1979; 1991).
In summary, Carroll's CSR definition offers a comprehensive understanding about a responsible business that should try to make profit, operate within the domain of the law, behave ethically and be a good corporate citizen. Because of its comprehensiveness, this study will employ this definition to formulate the interview questions and to develop the framework for data analysis.

\section{Research on CSR in Vietnam}

There is little scholarly and policy literature on CSR in Vietnam. The pioneering study on CSR in Vietnam was undertaken in 2004. This report was performed by Ministry of Labor-Invalids and Social Affairs, after the program of technical assistance "CSR in Vietnam," and supported financially and technically by the World Bank (Institute of Labour Science and Social Affairs 2004). After this report, a series of studies conducted by Centre Franco - Vietnamien de Formation A la Gestion was published in 2008.

Examining these studies, it is apparent that they have limited their research to workforce issues, labor relations, and environmental concerns (Chinh 2008; Huong 2008a; Huong 2008b; Nhu 2008). Since those studies, it can be said that CSR in Vietnam has been better understood as it raised awareness of such concerns. Additionally, the understanding about CSR provided by "Vietnam Forum on CSR" is noted in terms of the relationship between corporate and multi-stakeholders, the focus on labor and environment issues, and the role of corporations in economic and social benefits of stakeholders. One characteristic of most of these studies is that, unlike the research proposed here, there was a survey targeting management students in order to assess their perception about the CSR concept and CSR activities (Thang 2008). The study findings asserted 
that CSR "is a nearly unknown concept in Vietnam" and CSR is not taught or introduced to business students. According to the survey results, corporate donations are considered as the main activity of CSR.

Based on the literature on CSR in Vietnam, it can be concluded that CSR is an emerging business concept that has not been clearly understood and implemented, that research involving the participation of local managers is limited, and many of the reported perceptions about CSR, even though they might reflect those of managers, are largely drawn from student sample data.

\section{Methodology}

The main purpose of the study is to investigate managers' perceptions of CSR as well as evolving context affecting their perceptions. Therefore, the main method to collect data is in-depth interview with managers. Based on CSR definition of Carroll (1979), semi-structured interview questions are proposed. Those questions are to investigate mangers' awareness of CSR, their understanding of responsibilities a company must fulfill, and their view of the roles of government and professional associations. The salience of interviewing is to let informants talk freely about their thinking, understanding and opinions.

According to the needs of this study, various aspects of managers' understanding and perceptions, but not necessarily representativeness of all managers, need to be explored. To achieve this purpose, the sample must be chosen broadly in middle management level. This means that the sampling inquiries must result in being able how to collect a wide range of information (Boeije 2010).
Therefore, purposive and convenience sampling is the most appropriate one supporting to collect different viewpoints of informants (Miles and Huberman 1994, p.27). To approach appropriate respondents, a list was prepared. However, the list of interviewees was supplemented, when new and appropriate ones were recommended by other interviewees.

This study focuses on construction companies, especially on contractor corporations whose operations have a large impact on the society. The informants are middle managers, such as project managers, heads of project department or managers of sub-companies of nine construction companies (see table 1 and 2 ). The argument for this selection is that those managers occupy the positions in the construction companies appropriate to be informants (ed. Flick, Kardorff et al. 2004). Furthermore, middle managers are the ones breaking corporate objectives into smaller targets (Bateman and Scott 2011). The sampling did not consist of front-line managers. In the construction industry in Vietnam, front-line managers have a high turn-over rate; changing jobs, projects and employers frequently, thus making it difficult to conduct appropriate and effective sampling of this group. In addition, front-line managers have a more limited role in the organization, especially with regard to their informational role (Jones and George 2008). As such, while it would be worthwhile to include frontline managers so as to be able to compare their perceptions with those of senior and middle managers, the pragmatic difficulties in doing so ruled this option out for the research. 
Table 1. Demographic information of interviewees

\begin{tabular}{|c|c|c|c|c|}
\hline Manager & Position & Age & Gender & $\begin{array}{c}\text { Years in management } \\
\text { position }\end{array}$ \\
\hline Manager A2 & Head of subsidiary & 1956 & Male & 16 \\
\hline Manager B2 & Head of project department & 1975 & Male & 4 \\
\hline Manager C2 & Project manager & 1982 & Male & 2 \\
\hline Manager E2 & Head of HR department & 1975 & Female & $<1$ \\
\hline Manager F1 & Project manager & 1979 & Male & 5 \\
\hline Manager G1 & Joint-stock & 1980 & Male & 3 \\
\hline Manager H2 & Head of subsidiary & 1956 & Male & 18 \\
\hline Manager J1 & Project manager & 1982 & Male & 6 \\
\hline Manager K2 & Head of Project department & 1975 & Male & 6 \\
\hline
\end{tabular}

Among those companies, there are 7 contractors, 1 designing company and 1 producing construction material company. Companies in the sample, even large or small businesses, include different types of ownership, such as state-owned, joint stock and private ones (see table 2). All needed data was collected in the last 6 months of 2011 .

Table 2. Main activities, size and ownership of studied companies

\begin{tabular}{|c|c|c|c|}
\hline Company & Onwership & Main activities & No. of employees \\
\hline Company A & Joint-stock & Design and consultant & 213 \\
\hline Company B & Joint-stock & Contractor & 150 \\
\hline Company C & Joint-stock & Contractor & 3,200 \\
\hline Company E & State-owned & Contractor & 1,500 \\
\hline Company F & Private & Contractor & 3,000 \\
\hline Company G & Joint-stock & Contractor & 50 \\
\hline Company H & Private & Construction manufacturer & $>1,000$ \\
\hline Company J & Joint-stock & Contractor & 250 \\
\hline Company K & Joint-stock & contractor & 94 \\
\hline
\end{tabular}

Eventually, thematic analysis is employed to address the research questions. According to Gibson and Andrew (2009), thematic analysis serves three main aims, including examining commonality, examining differences and examining relationships. With those aims, thematic analysis fits the research purposes properly.

\section{Research findings}

This research is undertaken in the construction industry in order to investigate what managers' understanding of CSR. Therefore, in this section, identified CSR-relating issues are presented. It is necessary to figure out all aspects in informants' talking about CSR from their personal views. The section is structured with two key parts addressing the research objectives. First is about managers' awareness of CSR. Identified issues include environmental issues, contribution to the society, corporate reputation and prestige, 
economic and legal issues, ethical issues and philanthropic issues. Second is about the roles of government and professional associations in encouraging businesses to adopt CSR in their operations.

\section{Managers' awareness of CSR}

\section{Environmental issues}

Surprisingly, most of informants did mention about the environmental issues in their talks as one of important issues in doing business in the construction sector. When asked about what they think of CSR, interviewed managers talked about the environment, including working environment, social environment or general environment. Some of them discussed about improving the environment by saying "any enterprise, in term of economic aspect, has to return to serve community by improving environment" (Manager H2, research interview, 2011). While others highlighted that construction companies in their execution or in their sites should not do anything having bad influence on environment. As expressed by a young manager "I think CSR is ... what we have done don't have bad influence on environment ..." (Manager C2, research interview, 2011). A similar opinion shared by other manager is "I think it needs to perform a project in the best way to make sure that there is no bad effect on the environment" (Manager G1, research interview, 2011). A very young manager in a private construction company mentioned that "when doing business, we have to try to keep working environment tidy ...... we have the responsibility to do environment sanitation" (Manager F1, research interview, 2011).

\section{Contribution to the society}

Contribution to the society is the next frequently-mentioned issue in interviews. Managers actually perceive about the responsibility of contributing to society of companies and of individuals who are working in those companies.

Managers in sampling state that a company through its operation must contribute something to society. Emerged terms are "serve social development", "serve community", "make benefit by intangible effects", and "contribution to the society". Different activities are mentioned to express how a company contributes to society. The CSR interventions are mainly expressed by successes of businesses to make a better society in quality of life, infrastructure, urban aesthetics, or social assets. As articulated by a manager in a large construction corporation "it contributes to develop infrastructure not only for the company, but also for the society" (Manager E2, research interview, 2011). Or, a manager explains a construction company's contribution with its intangible benefits to society "... people can admire projects, such as the highest building in Hochiminh city in Ham Nghi street ... it is a kind of benefits ... a benefit of ..." (Manager B2, research interview, 2011). Some managers explicate that in practicing CSR, paying tax as much as they can is also a way to contribute to society and community. A young project manager in a large construction company expresses his view "Doing a profitable business can contribute to society through paying tax. A developed government will push society develop" (Manager C2, research interview, 2011).

Although most of respondents believe that this responsibility is of companies, there are ideas about their personal efforts also being devoted to society and community through the operation of their companies. It is highlighted, from their view, in professional aspect to perform their occupation to provide the best products. An aged manager indicates that "responsibilities of the company and 
individuals are to perform our professional major to meet the requirements of society and it is improved gradually in order to provide society with the best products. Those are the responsibilities for society. In term of responsibility in major of each employee, it must be better gradually. That is my responsibility for society in professional aspect." (Manager A2, research interview, 2011)

\section{Corporate reputation and prestige}

One issue that most of interviewed managers mention when talking about CSR is corporate reputation and prestige. They include building reputation and prestige as a responsibility that companies have to fulfill to respond to society and community's expectation. An aged manager asserts that "At the beginning, they don't have awareness of responsibilities. However, gradually, to a certain time, they do feel that ... that ... that ... they need to perform in that way. Responsibility is to build a prestige brand for the company. That needs to be done." (Manager H2, research interview, 2011). Similarly, a young manager highlights with his thinking "because our company wants to become a prestige contractor, not only in Vietnam but also in the foreign market in the near future" (Manager $F 1$, research interview, 2011). Other significance in doing business is quality control because it affects much corporate reputation and prestige. As expressed by a manager in a joint-stock company, "In execution, it needs to be checked to control quality, not let ... avoiding such and such problems influence quality of project, and company's prestige." (Manager C2, research interview, 2011).

\section{Economic and legal issues}

Consistently with the CSR pyramid of Carroll (1991), economic and legal issues are recognized by all interviewed managers as the first two obligations of companies.

All respondents assert that economic issue is an extremely cardinal responsibility of a company because it is the basic purpose when running a business. There is even an opinion about the only responsibility of making profit in the early days of a company. However, they understand and describe responsibilities relating to economic aspect in different ways. In their views, economic responsibilities manifest in a variety of activities, such as making jobs and guarantee employment for employees, making profit, offering effective operation, providing goodlooking and quality products, and success in business. Majority middle managers emphasize companies' duty of making profit. As expressed by a manager "Effective operation is a responsibility, exactly. It is because, broadly speaking, doing business must be profitable" (Manager C2, research interview, 2011). Or similar thinking is articulated by another manager, noting that "being $a$ profitable business can be considered as responsible for society" (Manager J1, research interview, 2011). Other mostlyconcerned issue is making job, guarantee employment, improving working life for employees. One manager states, "I think, a business must guarantee employment for its employees... because if they have their jobs, they can earn money, they will live better." (Manager G1, research interview, 2011). The quality of construction products is also mentioned by managers when talking about economic aspect. As highlighted by an engineer-manager in a design and consulting company "responsibilities of a company and individuals are to perform our professional major to meet the requirements of society and it is improved gradually in order to provide society with the best products" 
(Manager A2, research interview, 2011) or by a manager in a contractor "Doing profitable business means ... building up many projects which are good-looking and quality products" (Manager C2, research interview, 2011).

Regarding legal issue, they all perceive its significance. Some even link legal responsibilities to the competition in market; therefore, to survive, companies must strictly follow and obey relating rules, regulations and laws. Majority of interviewed managers confirm that companies are not allowed to do anything wrongly and they must be transparent, to wit: construction companies have to be aware of and properly perform any requirements from government, industry or any relating agencies as ground rules. When asked about a company's responsibilities toward society, a young manager of a contractor expresses his understanding as "I think, a company must do its business legally, clearly, and transparently..." (Manager J1, research interview, 2011). Or, other manager articulates "The construction industry has its contribution to the society not only in the use of production, but also in following strictly the rules and requirements. For example: buying insurance for surrounding areas." (Manager K2, research interview, 2011). There is a manager who even explains CSR as not breaking laws when running business, noting as "Trying not breaking laws and requirements is practicing CSR, because if anything happens, the company goes bankrupt" (Manager H2, research interview, 2011). Professional standards which are applied in construction majors are also categorized in legal aspect because respondents note them as extremely pivotal requirements. One manager indicates "... we may adopt American standards, or Britain or Japanese standards ... but it must ensure strictly following Vietnamese standards. For example, to this project, we are adopting American standards ... all drawings ... but these standards must satisfy those of Vietnam and all have to obey strictly laws and legal requirements. There is nothing out of laws, even designing a beam, or a slab ..." (Manager A2, research interview, 2011).

\section{Ethical issue}

When asked about even if there are any responsibilities not documented in laws, but expected by society, majority of participants mention regarding occupational conscience, professional ethics and business ethics, even a company or individuals. According to their understanding, the issue of how those terms are understood depends much on each company, each individual, because "Legal documents are an issue, but applying is another issue, to wit: a document can be understood in many ways ... It is beyond laws, rules and regulations" (Manager A2, research interview, 2011). Under the umbrella of CSR, ethical responsibilities are somewhat "are expected or prohibited by societal members even though they are not codified into law" (Carroll 1991); and interviewed managers perceive the existence of those responsibilities. When asked, a manager immediately talks about occupational conscience - "Actually, that conscience is not required by laws or construction requirements ... Truly, it depends on each individual, each company. It looks like ...... how to say ... looks like being responsible for your duties, never let bad practices ... it looks like professional ethics. It means that we do it more carefully and better ..." (Manager B2, research interview, 2011).

Nevertheless, there is an aged manager not agreeing when asked about professional ethics or conscience. In his view, all requirements are documented 
legally and there is not more expectation. Companies and individuals don't need to consider what should or should not do.

\section{Philanthropic issue}

Without exception, participated managers describe CSR practices through charitable and voluntary activities, such as building charity house, offering scholarship funding. As expressed by a manager, "practicing CSR is through taking partly profit to ... building charity houses, or performing voluntary activities ... That is duty a company needs to do and ... must do. That is duty besides professional responsibilities ... Taking partly profit to do and gathering people participating ..." (Manager A2, research interview, 2011). In some managers' view, philanthropy is an obvious part of CSR practices. To answer the question of what CSR is, a young manager lists some activities, from his opinion, expressing CSR "performing CSR is to increase the working life and social life of employees, or doing philanthropic activities ... CSR includes many things." (Manager K2, research interview, 2011).

Nevertheless, there are some managers who don't agree that discretionary activities are businesses' responsibility. From their view, charitable practices are something that a company should do if it has enough capabilities to fulfill. As expressed by a manager, noting that "These activities are philanthropic, they are not corporate responsibility." (Manager G1, research interview, 2011). There even is a manager highlighting that philanthropic activities only can be corporate responsibility, if it is stated in company's mission. "If so, in mission, company has to state ... it will have to do that issue, right? We will do charitable activities ... we will participate social events ... If so, it is their responsibilities.
However, I think, missions and visions of companies are not stated in that way, right?" (Manager J1, research interview, 2011).

\section{Roles of government and} professional associations

All respondents acknowledge and emphasize significant roles of government in encouraging business to adopt CSR. They all recognize the role of government in issuing policies in applying CSR practices to establish a legal foundation for all companies, controlling and supporting businesses in implementing those policies in practice. Other role that informants think government needs to fulfill is to orient, to direct companies to be familiar with higher requirements and to disseminate necessary and required information to business as soon as possible. As articulated by a project manager "I think, the role of government is very important in controlling and supporting businesses, in issuing appropriate policies. It helps companies much in implementing CSR." (Manager G1, research interview, 2011). Furthermore, government is also expected in making change awareness of society by issuing policies affecting other sectors, such as education. It is because, from their view, "Awareness of the society is more important, documented laws cannot do anything" (Manager A2, research interview, 2011). Nevertheless, from interviewed managers' opinions, government hasn't properly performed its roles, currently. As expressed by a young manager "In fact, the role of government is to issue policies and directions. Supporting ... I have not seen any. I hope there will be supporting from government in the future." (Manager F1, research interview, 2011).

In the opinion of the interviewees professional associations do not appear 
to play a significant role. There are even two executives who don't know anything about associations. When asked about the roles of professional associations in CSR, most of interviewed managers didn't even discuss the role of industry bodies. Typically, the responses were reflected in the comments of one middle-aged manager who responded "I don't know. I cannot see any influences from them ..." (Manager $B 2$, research interview, 2011). According to an aged manager, associations used to be so good in the planned economy and used to have impacts on the industry, "Previously, in the planned economy, those associations had their influence, but now ... they ... seemingly have very little impact on major, they have very little information ... They look like a panels advising for People Committee. They are representative for many members ... However, their operations are so limited and their members are not good in major ... Moreover, companies can solve their problems, they don't need ..." (Manager $A 2$, research interview, 2011)

\section{Discussion}

The emerging themes identified in this research leads to following discussion.

First, although Vietnam is a developing country, the environmental awareness of managers has been dramatically expressed. Executives, irrespective of age, acknowledge the importance of environment, including working environment, social environment or general environment and they categorize environmental responsibility into CSR. The awareness has just reached to the beginning concern about environment. In fact, current execution in construction sites in Vietnam has raised many problems in the environment. However, the concern of construction managers is only to "not impacting badly the environment or keeping it tidy", but not to specific solutions or execution methods.

Second, despite not being clearly expressed, it is worth noting that most managers acknowledge businesses' and individuals' responsibility in contributing to society. A responsibility that construction companies must fulfill is to contribute to society and surrounding community, even physical assets like infrastructure or intangible benefits like urban aesthetics. This awareness can be explained by the roles of construction companies, especially of construction engineers and architects in designing and developing the cities and their infrastructure. Additionally, corporate reputation and prestige is also an expectation of society. The reason used to explain those thinking may be rooted from a desire of making a wealthy society.

Third, perceptions of executives as to responsibilities of businesses closely accord with Carroll's CSR pyramid (1991). It is because, on the one hand, their awareness fits Carroll's CSR pyramid in the first two responsibilities as required by society or stakeholders. All interviewed executives prioritize economic obligations, which companies have to fulfill, relating to making profit, providing quality products, guaranteeing employment, being successful business. Those aspects are reflecting economic motive of business entities. Furthermore, managers also perceive that all business operations must be complied closely with laws, rules and regulations of the construction industry, relating agencies, and government. Obeying laws is, obviously, categorized as a fundamental condition for a company to survive in competitive market. On the other hand, when it comes to ethical and philanthropic responsibilities, executives don't have similar perceptions. According to Carroll (1991), ethical responsibilities refers to 
something "that are expected or prohibited by societal members even though they are not codified into law". Appropriately, professional ethics or conscience, which is not required by laws, exemplifies society's expectation. In addition, there is the fact that the understanding of legal documents is depended much on related persons and companies. This fact may arise from the legal context in Vietnam which is not strict enough. Philanthropic responsibilities likewise are perceived and categorized differently. Even though discretionary obligations are usually understood as CSR, those are denied by some young managers. The reason of this issue may be explained that young managers belong to new management generation who are influenced much by different cultures. Nevertheless, it can be concluded that Carroll's CSR pyramid can be used as a framework for research on CSR in Vietnam.

Finally, all interviewed executives expect government to issue appropriate policies to encourage businesses to adopt CSR. They even have some specific suggestions. Importantly, some of those suggestions mention about the treatments should be fair with all construction companies. The motivation from government policies is significantly impacted businesses CSR behaviors and practices. It may suggest that in developing countries like Vietnam, government and the governing body of the construction industry should focus on issuing consistent policies and strictly controlling the implication of those policies. Meanwhile, from executives' opinions, professional associations, seemingly, don't have any role in CSR practices. The roles of associations in the past were more significant and have been currently decreased. This finding as to roles of associations suggests an idea for industry governance in re-engineering and restructuring the purpose of associations. However, when asked, informants have suggestions and their expectations to government, but not to associations. This issue expresses that fact that they don't expect or believe in any professional associations. It becomes a big question for the industry and the existence of current associations as well in the current globalization context.

\section{Concluding remarks}

Basing on Carroll's CSR pyramid (1991), this paper employs four types of responsibilities, including economic, legal, ethical and philanthropic responsibilities, as the studied framework to investigate perceptions towards CSR of managers in construction companies in order to provide an initial assessment of awareness of CSR in Vietnam, an emerging country. Although Corporate Social Responsibility has offered breakthroughs in business, understanding, implementing and practicing in real business life is still limited. Especially, construction industry is the sector employing many labors and having many effects on the society (Ling, Pham et al. 2009).

Different middle managers in different construction companies are selected to participate in this research. Jobs of interviewed executives are diversified from project managers and heads of departments, to director of factory and manager of subsidiary (see table 1). Similarly, their ages are also different. Some of them are still very young and has experienced only some years in management positions, while some others are aged with a really long time in management. Even so, their understanding is quite clear. The findings from this study show that a business's social responsibilities are neither well, nor broadly agreed upon by the interviewed 
managers. However, executives in a developing country like Vietnam have seriously thought of the environmental issues and corporate contributions to society and surrounding communities as regards either tangible or intangible impacts.

Executives' perceptions of the role of government also emerged from the research. From executives' thinking, governments in developing countries like Vietnam are expected to be fair in treating, controlling and supporting enterprises in adopting CSR. It is because there is a need of more systematic planning and stronger efforts from government, to industry governance and to each company. Furthermore, an effective plan in practicing CSR requires the involvement and contribution not only of companies, but also of every individual staff in adopting CSR. Hence, their perceptions and understanding of CSR needs to be trained and oriented by studying, working in appropriate environments supporting and encouraging CSR.

Eventually, some limitations of this study should be recognized, especially regarding participants and studied corporations. This study approached middle managers only, but not top management level who are formulating corporate strategy and control resources (Bateman and Scott 2011). Besides, no managers from foreign construction corporation participated in this study. Future studies should recruit interviewees like General Directors, CEO in order to depict more detailed perspectives on strategic CSR. Moreover, approaching managers from foreign construction companies will help to identify how foreign corporations effect Vietnamese managers' perceptions on CSR.

\section{REFERENCES}

Agle, B R, Mitchell, R K \& Sonnenfeld, J A 1999, 'Who Matters to CEOs? An Investigation of Stakeholder Attributes and Salience, Corporate Performance, and CEO Values', The Academy of Management Journal, vol. 42, no. 5, pp. 507-525.

Bateman, T S \& Scott, S 2011, Management: leading and collaborating in a competitive world, 9th edn, McGraw-Hill Irwin, New York.

Berson, Y, Oreg, S \& Dvir, T 2008, 'CEO values, organizational culture and firm outcomes', Journal of Organizational Behaviour, vol. 29, pp. 615-633.

Bo, P V 2009, 'Vietnam country report'. in The 15th Asia construct conference, 2009, Kuala Lumpur Malaysia.

Boeije, H 2010, Analysis in qualitative research, SAGE, Los Angeles.

Carroll, a B 1979, 'A three dimensional conceptual model for corporate peformance', Academy of Management Review, vol. 4, no. 4, pp. 497-505.

Carroll, a B 1991, 'The pyramid of corporate social responsibility: toward the moral management of organizational stakeholders', Business Horizons, vol. 34, pp. 39-48.

Carroll, a B 1998, 'The four faces of corporate citizenship', Business and Society Review, vol. 100/101, pp. 1-7.

Chinh, N T 2008, 'Environment issues in Corporate Social Responsibility', International vision, vol. 12, pp. 77-86. 
Ciulla, J B 1999, 'The important of leadership in shaping business values', Long Range Planning, vol. 32, no. 2, pp. 166-172.

Dalton, D R \& Cosier, R A 1982, 'The four faces of social responsibility', Business Horizons, vol. 25, no. 3, pp. 19-27.

Flick, U, Kardorff, E V \& Steinke, I (eds.) 2004, A companion to qualitative research, SAGE, London.

Gibson, W J \& Andrew, B 2009, Working with qualitative data SAGE, London.

Huong, B T L 2008a, 'The perspective on Corporate social responsibility in emerging countries: the case of Vietnam', International vision, vol. 12, pp. 57-74.

Huong, N 2008b, 'Corporate social responsibility in Vietnam: from history to date', International vision, vol. 12, pp. 35-48.

Institute of Labour Science and Social Affairs 2004. Study on corporate social responsibility - labour-related practices. Study on Corporate Social Responsibility. Hanoi: Ministry of Labour-Invalids and Social affairs.

Jones, G R \& George, J M 2008, Contemporary management, 5th edn, McGraw-Hill/ Irwin, Boston.

Kotler, P \& Lee, N 2005, Corporate social responsibility-Doing the most good for your comapny and your cause, John Wiley \& Sons, Inc, Hoboken, New Jersey.

Ling, F Y Y, Pham, V M C \& Hoang, T P 2009, 'Strengths, Weaknesses, Opportunities, and Threats for Architectural, Engineering, and Construction Firms: Case Study of Vietnam', Journal of Construction Engineering and Management, vol. 135, no. 10, pp. 1105-1113.

Miles, M B \& Huberman, a M 1994, Qualitative data analysis : an expanded sourcebook, 2nd edn, SAGE, Thousand Oaks, Calif.

Murray, M\& Dainty,A2009, 'Corporate social responsibility:challenging the construction industry'. in: Murray, M. \& DAINTY, A. (eds.), Corporate social responsibility in the construction industry, Taylor \& Francis, London, pp. 3-23.

Nhu, T V 2008, 'Efficiency of integrating corporate social responsibility and environmentally friendly technology's application: a case study of leading coal manufacture company in Vietnam', International vision, vol. 12, pp. 119127.

Paine, L S 1996, 'Moral thinking in management: An essential capability', Business Ethics Quarterly, vol. 6, no. 4, p. 477.

Porter, M E \& Kramer, M R 2006, 'Strategy and Society - The link between Competitive advantage and Corporate Social Responsibility', Havard Business Review, vol. December 2006, pp. 78-92.

Quan, A 2010, 'Development of the construction leading in production sector', VnEconomy, 06 July 2010, http://vneconomy.vn/20100706101329701P0C17/ tang-truong-nganh-xay-dung-dan-dau-khoi-san-xuat.htm.

Thang, T T N 2008, 'Perception of corporate social responsibility in Vietnam', International vision, vol. 12, pp. 107-118.

Waldman, D A \& Siegel, D S 2008, 'Defining the social responsible leader', The Leadership Quarterly, vol. 19, pp. 117-131. 